\title{
Optimization and Identification of Lactic Acid Bacteria with Higher Mannitol Production Potential
}

Lejaniya Abdul Kalam Saleena ${ }^{1}$, Deepak Chandran², R. Geetha ${ }^{3}$, R. Radha ${ }^{3}$, C.T. Sathian ${ }^{3}$, Manoj Kumar ${ }^{4}$, R. Sureshkumar ${ }^{5}$, V. Marthandan ${ }^{5}$, Radha ${ }^{6}$

10.18805/IJAR.B-4759

\begin{abstract}
Background: Lactic acid bacteria (LAB) is considered as food-grade microorganism with generally recognized as safe (GRAS) status. Both hetero-fermentative and homo-fermentative LAB have the ability to produce mannitol as metabolic end product in normal fermentation. Methods: Ten LAB isolates selected were detected for its mannitol production potential using colorimetric assay in preliminary study. Later selected four isolates of LAB with better mannitol production were further optimized at different culture conditions. A total of 540 mannitol combinations were obtained after optimization. All the observations were statistically analyzed using response surface methodology. Biochemical and molecular assays were carried out to identify the isolates.

Result: The isolate L8 produced mean mannitol content of $1.635 \mathrm{~g} / \mathrm{L}, 0.345967$ cell densities, at $\mathrm{pH} 7.0$ and temperature $42^{\circ} \mathrm{C}$ with agitation of $100 \mathrm{rpm}$ was selected with optimum response surface optimization because of its higher mannitol production. Biochemical and molecular assays identified higher mannitol producers, L4 as Enterococcus faecium strain Gr17, L6 as Lactobacillus rhamnosus strain 6870, L8 as Leuconostoc pseudomesenteroides culture IMAU: 11666 and L9 as Lactobacillus plantarum subsp. plantarum strain NMB8.
\end{abstract}

Key words: Biochemical and molecular assay, Colorimetic assay, LAB, Mannitol, Sequencing.

\section{INTRODUCTION}

The diversity of natural lactic flora, was dominated by Lactococci, Enterococci, Lactobacilli, Pediococci and Leuconostocs (Dahou et al. 2020). Lactobacilli, Lactococci, Pediococci and Leuconostoc species were also isolated using ripened, aged fruits and vegetables by Padmaja et al. (2011). Lactic acid bacteria's functional attributes include probiotic activities, boosting nutritional density by sugar conversion, improving nutrient bioavailability, antibacterial and antioxidant activity, vitamin biosynthesis, antinutritive chemical breakdown and sensory quality enhancement. Several technologically relevant properties of lactic acid bacteria isolated from samples were investigated and exploited in order to maintain the dairy bacteria ecology live and functioning in today's technologically advanced world (Ketrouci et al. 2021). Species from the genera Leuconostoc, Oenococcus and Lactobacillus, in particular, have been found to successfully manufacture mannitol (Von Weymarn et al. 2002).

D-Mannitol is a sugar alcohol with six-carbon, considered to be half sweet as sucrose and have diverse applications in low-calorie foods and pharmaceuticals (Ojamo et al. 2003). Mannitol is partially metabolized by human and reduce hyperglycaemia in diabetic patients (Ruiz Rodriguez et al. 2017). Low-calorie sweeteners are applicable in foods and due to increased demand, wide varieties of low-calorie foods are available in the market. Mannitol production by food grade organism can act as natural sweetener in food products and thereby side effects of other artificial sweeteners can be reduced (Von Weymarn et al. 2002). Some strains of $L A B$ enhanced fructose
1Department of Food Science and Nutrition, Faculty of Applied Sciences, 1, UCSI Heights, Jalun Pancak Menara Gading, UCSI University, Taman Connaught, 56000 Cheras, Willayah Persekutuan Kuala Lampur, Malaysia.

${ }^{2}$ Department of Veterinary Sciences and Animal Husbandry, Amrita School of Agricultural Sciences, Amrita Vishwa Vidyapeetham University, Coimbatore-642 109, Tamil Nadu, India.

${ }^{3}$ Department of Dairy Science, College of Veterinary and Animal Sciences, Mannuthy, Thrissur-680 651, Kerala, India.

${ }^{4}$ Chemical and Biochemical Processing Division, ICAR-Central Institute for Research on Cotton Technology, Mumbai-400 019, Maharashtra, India.

${ }^{5}$ Amrita School of Agricultural Sciences, Amrita Vishwa Vidyapeetham University, Coimbatore-642 109, Tamil Nadu, India

${ }^{6}$ School of Biological and Environmental Sciences, Shoolini University of Biotechnology and Management Sciences, Solan-173 229, Himachal Pradesh, India.

Corresponding Author: Deepak Chandran, Department of Veterinary Sciences and Animal Husbandry, Amrita School of Agricultural Sciences, Amrita Vishwa Vidyapeetham University, Coimbatore-642 109, Tamil Nadu, India; Lejaniya Abdul Kalam Saleena, Department of Food Science and Nutrition, Faculty of Applied Sciences, 1, UCSI Heights, Jalun Pancak Menara Gading, UCSI University, Taman Connaught, 56000 Cheras, Willayah Persekutuan Kuala Lampur, Malaysia.

Email: c_deepak@cb.amrita.edu; lejaniya@gmail.com

How to cite this article: Saleena, L.A.K., Chandran, D., Geetha, R., Radha, R., Sathian, C.T., Kumar, M., Sureshkumar, R., Marthandan, V. and Radha (2022). Optimization and Identification of Lactic Acid Bacteria with Higher Mannitol Production Potential. Indian Journal of Animal Research. DOI: 10.18805/IJAR.B-4759.

Submitted: 25-08-2021 Accepted: 08-12-2021

Online: 18-01-2022 
consumption rate and greater mannitol output improved volumetric mannitol productivity as well (Helanto et al. 2005). By recycling intracellular $\mathrm{NADH}$, most heterofermentative lactic acid bacteria convert fructose to mannitol (Otgonbayar et al. 2011). Moreover, it is a food grade sweetener with Food and Drug Administration (FDA) endorsement with ADI of $0-50 \mathrm{mg} / \mathrm{kg}$ body weight. Considering these factors, this research work was undertaken with the objectives of identifying LAB with mannitol production potential and there by optimizing its fermentation conditions in a batch fermenter for obtaining maximum mannitol production.

\section{MATERIALS AND METHODS}

\section{Preparation of standard curve for mannitol estimation}

The experiment was conducted at Department of Dairy Science, College of Veterinary and Animal Sciences, Mannuthy, Kerala, India during 2019-2020. Calibration curve for mannitol was plotted according to Sanchez (1998).

\section{Optimization of culture conditions for maximal mannitol production}

\section{Effect of temperature, $\mathrm{pH}$ and agitation}

Effect of different temperatures, $\mathrm{pH}$ and agitation on specific growth rate and mannitol yield of superior LAB strains was studied in MRS growth media at batch bioreactor (Scigenics, India). Temperatures used for the study were $33^{\circ} \mathrm{C}, 37^{\circ} \mathrm{C}$ and $42^{\circ} \mathrm{C}$, while $\mathrm{pH}$ used for the study was $6,6.5$ and 7.0. On agitation, $100 \mathrm{rpm}$ were provided. Done research without agitation also.

\section{Identification of LAB isolates}

\section{Biochemical identification of LAB isolates}

\section{Primary tests}

Gram staining, motility test, catalase test, oxidase test, sugar utilization test, effect of different temperature, $\mathrm{pH}, \mathrm{NaCl}$ concentration on growth of isolates were studied.

\section{Secondary tests}

Gelatin liquefaction, production of ammonia from arginine, oligosaccharide production, bile tolerance test, phenylalanine deamination, urease test, indole test, methyl red test, Voges Proskauer test, citrate utilization test, production of gas from glucose and triple sugar iron (TSI) agar test were studied.

\section{Molecular identification of LAB strains}

\section{Preparation of bacterial DNA}

The method suggested by Salehi et al. (2005) was followed.

\section{Primers used}

\begin{tabular}{lcll}
\hline Target & Primer name & Direction & Sequence $\left(5^{\prime} \rightarrow 3^{\prime}\right)$ \\
\hline \multirow{2}{*}{ 16S rRNA } & 16S-RS-F & Forward & CAGGCCTAACACATGCAAGTC \\
& $16 S-R S-R$ & Reverse & GGGCGGWGTGTACAAGGC \\
\hline
\end{tabular}

PCR amplification, detection of PCR products and sequencing

Amplification was carried out in a PCR thermal cycler (T 100 Bio-Rad) with annealing temperature $60^{\circ} \mathrm{C}$ for 40 seconds in 35 cycles. Later $1.2 \%$ agarose gel electrophoresis was performed and visualized in a UV transilluminator (Genei) and Gel documentation system (EZI Imager, BioRad). Finally, were sequenced in Rajiv Gandhi Centre for Biotechnology, Trivandrum.

\section{Statistical analysis}

Six replications were carried out and the data was statistically analyzed using SPSS version 24.0. One Way ANOVA and dendrogram were used in the evaluation.

\section{RESULTS AND DISCUSSION}

Preliminary screening of ten LAB isolates for mannitol production

Standard mannitol curve (Fig 1), as suggested by Sanchez (1998) was prepared. Mannitol production by isolates was estimated after 18 hours of incubation at $37^{\circ} \mathrm{C}$ in MRS broth. Quantification of mannitol was done using linear regression equation obtained from standard curve.

$Y=a+b x, a=-706.454, b=11550.159, Y=$ mannitol concentration and $x=$ optical density value. The mannitol yield is shown in Table 1 . The values ranged from 0.36 to $0.65 \mathrm{~g} / \mathrm{L}$. Among the screened ones, isolates viz., L4, L6, L8 and L9 showed comparatively higher mannitol yield of $0.51,0.54,0.65$ and $0.57 \mathrm{~g} / \mathrm{L}$ respectively selected for further study. In a study conducted by Lactobacillus reuteri CRL 1101 was shown to be capable of producing mannitol effectively by Ortiz et al. (2017). According to Von Weymarn et al. (2002) Leuconostoc, Oenococcus and Lactobacillus, can produce mannitol. Cell density shows that mannitol production differs amongst LAB species with identical growth rates (Table 1). Helanto et al. (2005) observed maximum cell growth of Leuconostoc pseudomesenteroides, along with mannitol production $30^{\circ} \mathrm{C}, \mathrm{pH} 5$ and $200 \mathrm{rpm}$.

Optimization of the cultivation conditions for maximum mannitol production

Effect of varying temperature, $\mathrm{pH}$ and non-agitation on mannitol yield

Mean mannitol production by selected isolates at $33^{\circ} \mathrm{C}$ and different $\mathrm{pH}$ was in Table 2. All isolates produced significantly higher mannitol at $\mathrm{pH}$ 7.0. In fact, increasing the $\mathrm{pH}$ from 6.0 to 7.0 resulted in a small increase in productivity. Likewise, at $37^{\circ} \mathrm{C}$ all the isolates produced maximum mannitol at $\mathrm{pH}$ 7.0. Among that $\mathrm{L} 9$ produced higher mannitol 


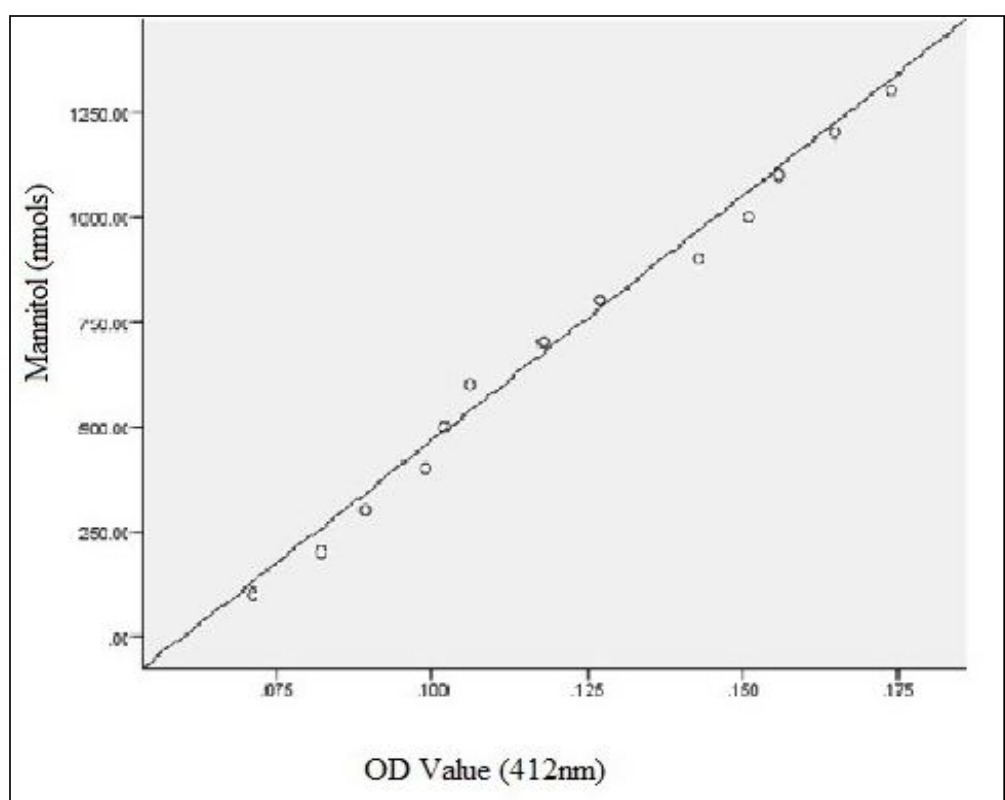

Fig 1: Calibration curve for mannitol estimation.

Table 1: Cell density and corresponding mannitol production of LAB strains.

\begin{tabular}{lcc}
\hline $\begin{array}{l}\text { LAB } \\
\text { strains }\end{array}$ & $\begin{array}{c}\text { Mean cell } \\
\text { density (OD value) }\end{array}$ & $\begin{array}{c}\text { Mean } \\
\text { mannitol }(\mathrm{g} / \mathrm{L})\end{array}$ \\
\hline L1 & 0.2341 & 0.42 \\
L2 & 0.1269 & 0.45 \\
L3 & 0.1038 & 0.43 \\
L4 & 0.2684 & 0.51 \\
L5 & 0.2257 & 0.48 \\
L6 & 0.2109 & 0.54 \\
L7 & 0.2781 & 0.36 \\
L8 & 0.2971 & 0.65 \\
L9 & 0.2506 & 0.57 \\
L10 & 0.1942 & 0.50 \\
\hline
\end{tabular}

of $1.30 \pm 0.27 \mathrm{~g} / \mathrm{L}$. Significantly no differences were observed in mannitol yield at different $\mathrm{pH}$. While at $42^{\circ} \mathrm{C}$, it is obvious from Table 3 that except L9, all other isolates showed a better productivity at $\mathrm{pH}$ 7.0. However, strain L4 showed significant difference in yield at different $\mathrm{pH}$.

Yun and Kim (1998) reported maximum production of mannitol of $73 \mathrm{~g}$ and $26 \mathrm{~g}$ from Lactobacillus species and Leuconostoc species respectively, at $35^{\circ} \mathrm{C}$ and $\mathrm{pH} 8.0$ and 6.0 respectively. In research conducted by Weymarn et al. (2002), mannitol production from Lactobacillus fermentum were estimated to be 86,89 and 94 mol per cent at $25^{\circ} \mathrm{C}$, $30^{\circ} \mathrm{C}$ and $35^{\circ} \mathrm{C}$ respectively. Volumetrically higher mannitol yield was detected at $35^{\circ} \mathrm{C}$ than at $25^{\circ} \mathrm{C}$ in Lactobacillus and Leuconostoc species. In a study conducted by Ojamo et al. (2003), higher mannitol production of $20 \mathrm{~g} / \mathrm{L} / \mathrm{h}$ was reported by Leuconostoc pseudomesenteroides ATCC 12291 strain at high cell density fermentation.
Effect of different temperature, $\mathrm{pH}$ and agitation on mannitol yield

When evaluating effect of agitation, $\mathrm{pH} 7.0$ shown to be the best for all isolates, resulting in significantly higher mannitol production at $33^{\circ} \mathrm{C}$ (Table 4$)$. The highest mannitol production was shown by isolate $\mathrm{L} 8(0.99 \pm 0.01 \mathrm{~g} / \mathrm{L})$ followed by L4, L9, and L6. Production of standard Leuconostoc mesenteroides was $0.89 \pm 0.02 \mathrm{~g} / \mathrm{L}$. At $37^{\circ} \mathrm{C}$ (Table 5) isolate L8 produced significantly higher mannitol of $1.17 \pm 0.04 \mathrm{~g} / \mathrm{L}$ at $\mathrm{pH}$ 6.5. Isolates didn't show any significant variation at $\mathrm{pH} 6.5$ and 7.0 . At $42^{\circ} \mathrm{C}$ with agitation the values ranged from $1.12 \pm 0.09 \mathrm{~g} / \mathrm{L}$ to $1.63 \pm 0.16 \mathrm{~g} / \mathrm{L}$, where peak mannitol production was by isolate $\mathrm{L} 8$ at $\mathrm{pH}$ 7.0. Yun and Kim (1998) specified that partial aeration was necessary for higher mannitol yield. Weymarn et al. (2002) observed an increase in mannitol production with Lactobacillus fermentum from $1.33 \pm 0.02$ to $1.65 \pm 0.06(\mathrm{~g} / \mathrm{L} / \mathrm{h})$ at semi anaerobic condition. Sugarcane molasses yielded the highest mannitol concentrations (38 and $41.5 \mathrm{~g} / \mathrm{L}$ ) when cultivated Lactobacillus reuteri in agitated cultures at $37^{\circ} \mathrm{C}$ (Ortiz et al. 2017). This finding was in harmony to the present exploration.

Effect of temperature, $\mathrm{pH}$ and agitation on bacterial cell density

Growth rate of all isolates was significantly different $(P \geq 0.05)$ in different conditions. While considering the non-agitated condition, isolate L8 showed significant difference in cell density on different $\mathrm{pH}$ at $33^{\circ} \mathrm{C}$ and $42^{\circ} \mathrm{C}$. L6 showed significant difference in cell density at $33^{\circ} \mathrm{C}$ and $37^{\circ} \mathrm{C}$, whereas $\mathrm{L} 4$ showed significant difference in cell density only at $42^{\circ} \mathrm{C}$. With respect to condition of agitation at $100 \mathrm{rpm}$, significant difference was noted in cell density for isolate L9 and L6 at all temperatures studied. Isolate L4 showed 
significant difference at $33^{\circ} \mathrm{C}$ and $37^{\circ} \mathrm{C}$, whereas $\mathrm{L} 8$ at $33^{\circ} \mathrm{C}$ and $42^{\circ} \mathrm{C}$. Significantly higher growth rate was observed in agitated cultures than non-agitated. Hence by proper agitation, temperature and $\mathrm{pH}$ the yield of mannitol by different lactic acid bacteria can be improved.

Grobben et al. (2001) opined higher production of mannitol of $75 \mathrm{mM}$ by Leuconostoc pseudomesenteroides with high cell density at $30^{\circ} \mathrm{C}$ and $\mathrm{pH} 4.5$. Weymarn et al. (2002) observed that growth rate of all strains increased in semi anaerobic condition, in accordance to present findings. Ojamo et al. (2003) reported higher mannitol production by Leuconostoc pseudomesenteroides with high cell density. Helanto et al. (2005) observed maximum cell growth of Leuconostoc pseudomesenteroides, at $30^{\circ} \mathrm{C}$ temperature, $\mathrm{pH} 5$ and $200 \mathrm{rpm}$ agitation.

\section{Selection of superior lab isolate by response surface methodology}

A total of 540 combinations were obtained and statistically analyzed using response surface methodology (Kumari et al. 2016). Dendrogram is shown in Fig 2. The $16^{\text {th }}$ cluster produced higher mannitol concentration of $1.6209 \mathrm{~g} / \mathrm{L}$ with 0.2799 optical density of cell growth. Sixteenth cluster included 2 combination studies with agitation (100 rpm), of isolate L8 with $1.6067 \mathrm{~g} / \mathrm{L}$ mannitol and $0.213767 \mathrm{OD}$ value at $\mathrm{pH} 6.5,42^{\circ} \mathrm{C}$, later with $1.635 \mathrm{~g} / \mathrm{L}$ mannitol and 0.345967 $\mathrm{OD}$ at $\mathrm{pH} 7.0,42^{\circ} \mathrm{C}$. From these second one was selected as the best. Using cluster and dendrogram analysis, mannitol producer (9.46 $0.27 \mathrm{~g} / \mathrm{l})$ strain F. tropaeoli was discovered from fruits by Ruiz Rodriguez et al. (2017). With a maximum volumetric productivity of $2.36 \mathrm{~g} / \mathrm{h}$ and the highest yield, of mannitol was obtained for $L$. fructosum NRRL B-2041 according to Carvalheiro et al. (2011). Also, different Leuconostoc pseudomesenteroides strains were studied for its higher mannitol production potential at different growth conditions (Bhatt et al. 2013).

\section{Identification of lab isolates}

\section{Biochemical identification}

Most of the phenotypical and biochemical characteristics of strains, L4, L6, L8 and L9 were explained in Fig 3. Sugar fermentation tests, growth condition studies and other biochemical studies proved that the isolate $L 4$ was Enterococcus sp. L8 was Leuconostoc sp. and L6 and L9 belong to Lactobacillus sp. according to Bergey's Manual of Determinative Bacteriology.

Table 2: Mean mannitol production by LAB strains at $33^{\circ} \mathrm{C}$ and different $\mathrm{pH}$.

\begin{tabular}{llllll}
\hline $\mathrm{pH}$ & $\mathrm{S}(\mathrm{g} / \mathrm{L})$ & $\mathrm{L} 4(\mathrm{~g} / \mathrm{L})$ & $\mathrm{L} 6(\mathrm{~g} / \mathrm{L})$ & $\mathrm{L} 8(\mathrm{~g} / \mathrm{L})$ & $\mathrm{L9}(\mathrm{g} / \mathrm{L})$ \\
\hline 6.0 & $1.16 \pm 0.07^{\mathrm{ns}}$ & $0.93 \pm 0.1^{\mathrm{b}}$ & $0.96 \pm 0.03^{\mathrm{c}}$ & $0.95 \pm 0.05^{\mathrm{b}}$ & $0.92 \pm 0.02^{\mathrm{b}}$ \\
6.5 & $1.25 \pm 0.04^{\mathrm{ns}}$ & $1.11 \pm 0.05^{\mathrm{ab}}$ & $1.17 \pm 0.03^{\mathrm{b}}$ & $1.29 \pm 0.02^{\mathrm{a}}$ & $1.18 \pm 0.05^{\mathrm{a}}$ \\
7.0 & $1.31 \pm 0.04^{\mathrm{ns}}$ & $1.22 \pm 0.04^{\mathrm{a}}$ & $1.28 \pm 0.02^{\mathrm{a}}$ & $1.26 \pm 0.04^{\mathrm{a}}$ & $1.23 \pm 0.04^{\mathrm{a}}$ \\
\hline
\end{tabular}

Each value is a mean of six observations with $S E$, means with different superscript in same column differ significantly ( $p \leq 0.05)$, ns-non significant $(p>0.05)$.

Table 3: Mannitol production by selected lactic acid bacterial strains at $42^{\circ} \mathrm{C}$ and different $\mathrm{pH}$.

\begin{tabular}{llllll}
\hline $\mathrm{pH}$ & $\mathrm{S}(\mathrm{g} / \mathrm{L})$ & $\mathrm{L} 4(\mathrm{~g} / \mathrm{L})$ & $\mathrm{L} 6(\mathrm{~g} / \mathrm{L})$ & $\mathrm{L} 8(\mathrm{~g} / \mathrm{L})$ & $\mathrm{L9}(\mathrm{g} / \mathrm{L})$ \\
\hline 6.0 & $0.82 \pm 0.01^{\mathrm{b}}$ & $0.56 \pm 0.06^{\mathrm{b}}$ & $0.73 \pm 0.09^{\text {ns }}$ & $0.83 \pm 0.08^{\text {ns }}$ & $0.81 \pm 0.11^{\text {ns }}$ \\
6.5 & $0.99 \pm 0.01^{\mathrm{a}}$ & $0.76 \pm 0.10^{\mathrm{ab}}$ & $0.86 \pm 0.11^{\text {ns }}$ & $1.00 \pm 0.11^{\text {ns }}$ & $1.04 \pm 0.15^{\text {ns }}$ \\
7.0 & $1.02 \pm 0.07^{\mathrm{a}}$ & $0.91 \pm 0.13^{\mathrm{a}}$ & $0.88 \pm 0.12^{\text {ns }}$ & $1.13 \pm 0.13^{\text {ns }}$ & $0.87 \pm 0.11^{\text {ns }}$ \\
\hline
\end{tabular}

Each value is a mean of six observations with $S E$, means with different superscript in same column differ significantly ( $p \leq 0.05)$, ns-non significant $(p>0.05)$.

Table 4: Mean mannitol production by selected lactic acid bacterial strains at $33^{\circ} \mathrm{C}$ and different $\mathrm{pH}$ on agitation.

\begin{tabular}{llllll}
\hline $\mathrm{pH}$ & $\mathrm{S}(\mathrm{g} / \mathrm{L})$ & $\mathrm{L} 4(\mathrm{~g} / \mathrm{L})$ & $\mathrm{L} 6(\mathrm{~g} / \mathrm{L})$ & $\mathrm{L} 8(\mathrm{~g} / \mathrm{L})$ & $\mathrm{L9}(\mathrm{g} / \mathrm{L})$ \\
\hline 6.0 & $0.72 \pm 0.02^{\mathrm{b}}$ & $0.73 \pm 0.0 .2^{\mathrm{c}}$ & $0.65 \pm 0.01^{\mathrm{c}}$ & $0.72 \pm 0.02^{\mathrm{c}}$ & $0.66 \pm 0.01^{\mathrm{c}}$ \\
6.5 & $0.75 \pm 0.03^{\mathrm{b}}$ & $0.83 \pm 0.02^{\mathrm{b}}$ & $0.72 \pm 0.01^{\mathrm{b}}$ & $0.91 \pm 0.02^{\mathrm{b}}$ & $0.81 \pm 0.01^{\mathrm{b}}$ \\
7.0 & $0.89 \pm 0.02^{\mathrm{a}}$ & $0.93 \pm 0.03^{\mathrm{a}}$ & $0.81 \pm 0.01^{\mathrm{a}}$ & $0.99 \pm 0.01^{\mathrm{a}}$ & $0.91 \pm 0.01^{\mathrm{a}}$ \\
\hline
\end{tabular}

Each value is a mean of six observations with $S E$, means with different superscript in same column differ significantly ( $\leq \leq 0.05)$.

Table 5: Mean mannitol production by selected lactic acid bacterial strains at $37^{\circ} \mathrm{C}$ and different $\mathrm{pH}$ on agitation.

\begin{tabular}{llllll}
\hline $\mathrm{pH}$ & $\mathrm{S}(\mathrm{g} / \mathrm{L})$ & $\mathrm{L} 4(\mathrm{~g} / \mathrm{L})$ & $\mathrm{L} 6(\mathrm{~g} / \mathrm{L})$ & $\mathrm{L} 8(\mathrm{~g} / \mathrm{L})$ & $\mathrm{L9}(\mathrm{g} / \mathrm{L})$ \\
\hline 6.0 & $0.78 \pm 0.01^{\mathrm{b}}$ & $0.80 \pm 0.02^{\mathrm{b}}$ & $0.87 \pm 0.03^{\mathrm{b}}$ & $0.90 \pm 0.03^{\mathrm{b}}$ & $0.86 \pm 0.03^{\mathrm{b}}$ \\
6.5 & $1.03 \pm 0.03^{\mathrm{a}}$ & $1.05 \pm 0.05^{\mathrm{a}}$ & $1.00 \pm 0.05^{\mathrm{a}}$ & $1.17 \pm 0.04^{\mathrm{a}}$ & $0.99 \pm 0.03^{\mathrm{a}}$ \\
7.0 & $1.12 \pm 0.04^{\mathrm{a}}$ & $1.03 \pm 0.04^{\mathrm{a}}$ & $1.04 \pm 0.05^{\mathrm{a}}$ & $1.16 \pm 0.04^{\mathrm{a}}$ & $1.08 \pm 0.03^{\mathrm{a}}$ \\
\hline
\end{tabular}

Each value is a mean of six observations with $S E$, means with different superscript in same column differ significantly ( $\leq \leq 0.05)$. 


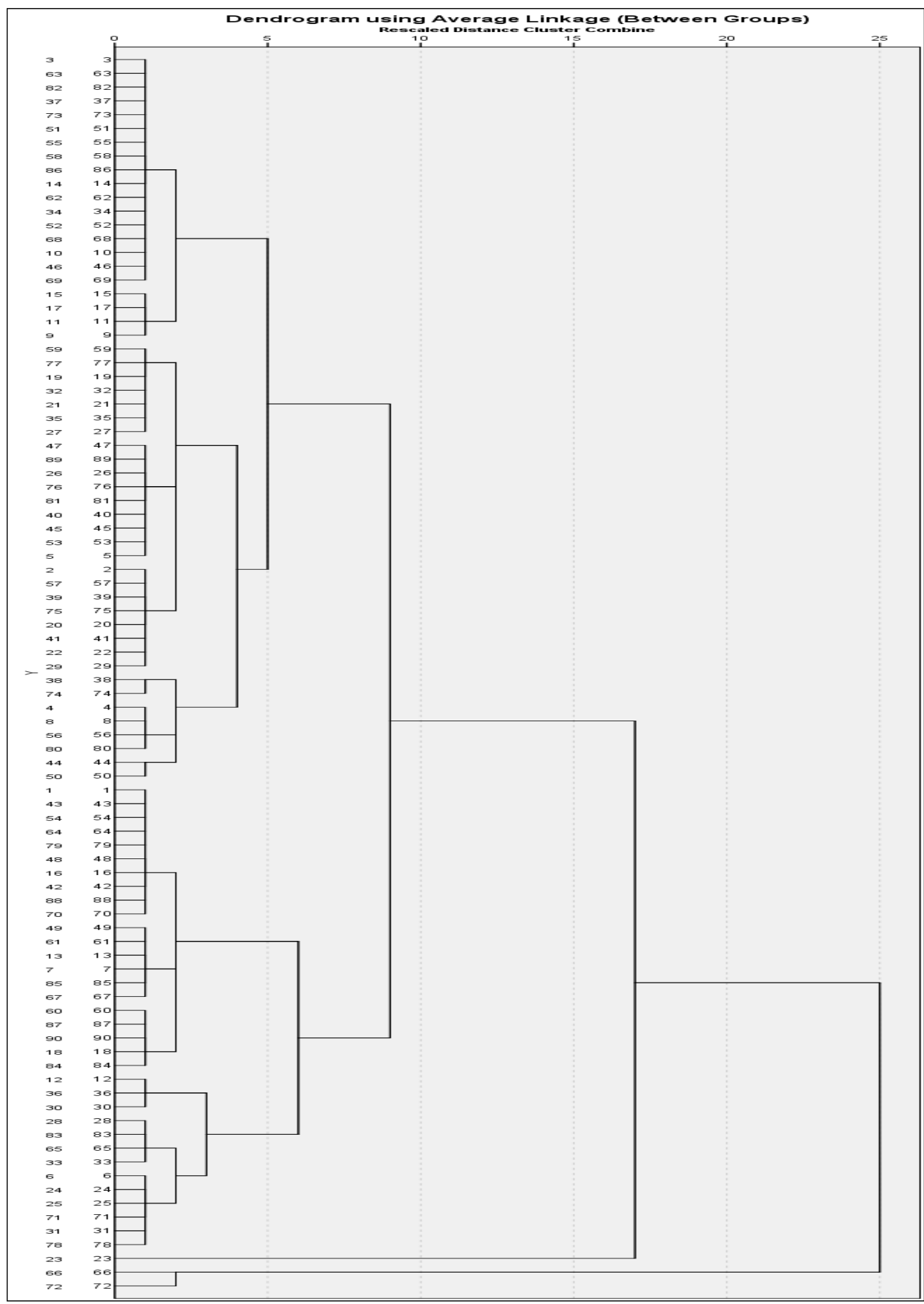

Fig 2: Representation of dendrogram. 
In a study conducted by Makanjuola and Springham (1984), Leuconostoc sp. was able to produce gas from glucose, ammonia from arginine and also showed growth at $15^{\circ} \mathrm{C}$ and $45^{\circ} \mathrm{C}$. Fermentation results of rhamnose and arabinose support the present study to characterize L8 isolate as Leuconostoc sp. Gancel et al. (1997) identified genus Lactobacillus from vacuum packed fish meat by biochemical characterization with tolerance of high levels of $\mathrm{NaCl}$, bile salts and $\mathrm{CO}_{2}$ production. But in present study all the isolates of LAB L4, L6, L8 and L9 were intolerant to higher concentration $\mathrm{NaCl}$. In different studies (Azadnia and
Nazer, 2009; Nair and Surendran, 2005) fermentation of specific sugars were observed for Lactobacillus species especially $L$. plantarum. These observations are related to the results obtained for $\mathrm{L} 9$ isolate in the present study. Also, Bhatt et al. (2012) used bile tolerance test in LAB identification. According to Hassanzadazar et al. (2012) all LAB strains isolated could not tolerate the $\mathrm{pH} \leq 2$ and the presence of bile salts, which agree with the existing results. Sugar fermentation assays and growth of LAB at different conditions in the above investigation were supportive to the present study.

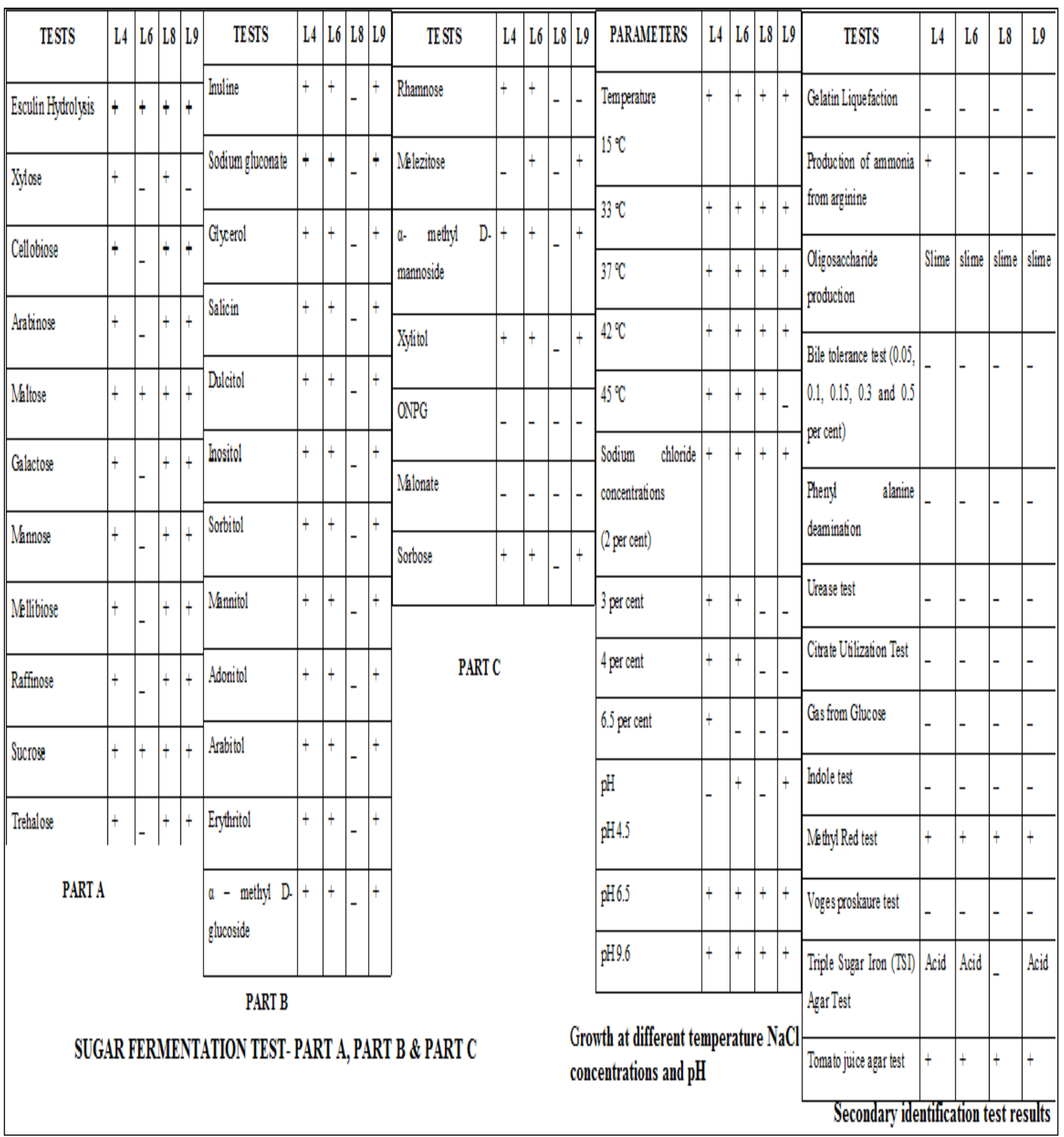

Fig 3: Results of biochemical tests. 


\section{Molecular characterization of LAB strains}

Sequencing result confirmed L4 as Enterococcus faecium strain Gr17, L6 as Lactobacillus rhamnosus strain 6870, L8 as Leuconostoc pseudomesenteroides culture IMAU: 11666 and L9 as Lactobacillus plantarum subsp. plantarum strain NMB8. Bacterial species identification by $16 \mathrm{~S}$ rRNA-based technique is the most accepted, as large public-domain sequence databases are accessible in Gene Bank for comparison (Morgan et al., 2009; Sharif et al., 2018).

\section{CONCLUSION}

In the present study an attempt was made to isolate and characterize $L A B$, which show higher mannitol production. Ten isolates were screened for mannitol production potential. The effects of temperature, $\mathrm{pH}$ and agitation on mannitol production were studied. Where Leuconostoc mesenteroides was used as control. Isolate L8 was identified as the most superior mannitol producer among the screened strains. Higher mannitol producing four isolates (L4, L6, L8, L9) were characterized biochemically as Enterococcus sp., Lactobacillus sp. and Leuconostoc sp. Later on, L4, L6, L8, L9 were identified as Enterococcus faecium strain Gr17, Lactobacillus rhamnosus strain 6870, Leuconostoc pseudomesenteroides culture IMAU: 11666 and Lactobacillus plantarum subsp. plantarum strain NMB8 respectively via molecular method.

\section{REFERENCES}

Azadnia, P.K.N.A. and Khan Nazer, A.H. (2009). Identification of lactic acid bacteria isolated from traditional drinking yoghurt in tribes of Fars province. Iranian Journal of Veterinary Research. 10: 235-240.

Bhatt, V.D., Vaidya, Y.H., Kunjadia, P.D., Kunjadia, A.P. and Patel, R. (2012). Isolation and characterization of probiotic bacteria from human milk. International Journal of Pharmacology and Scientific Health Care. 3: 62-70.

Bhatt, S.M., Mohan, A. and Srivastava, S.K. (2013). Challenges in Enzymatic Route of Mannitol Production. International Scholarly Research Notices. 2013: 13.

Carvalheiro, F., Moniz, P., Duarte, L.C., Esteves, M.P. and Gírio, F. M. (2011). Mannitol production by lactic acid bacteria grown in supplemented carob syrup, Journal of Industrial Microbiology and Biotechnology. 38: 221-227.

Dahou, A.A., Bekada, M., Mostefa, T., Rechidi, H., Homrani, S., Elamine, A. and Dahou. (2020). Characterization of Natural Lactic Flora in a Soft Cheese "Camembert of the Tessala" Made from Thermised Milk of Local Breed Cow "Brown of the Atlas". Asian Journal of Dairy and Food Research. 39: 30-34.

Gancel, F., Dzierszinski, F. and Tailliez, R. (1997). Identification and characterization of Lactobacillus species isolated from fillets of vacuum-packed smoked and salted herring (Clupeaharengus). Journal of Applied Microbiology. 82: 722-728.

Grobben, G.J., Peters, S.W., Wisselink, H.W., Weusthuis, R.A., Hoefnagel, M.H., Hugenholtz, J. and Eggink, G. (2001).
Spontaneous formation of a mannitol-producing variant of Leuconostoc pseudomesenteroides grown in the presence of fructose. Applied Environmental Microbiology. 67: 2867-2870.

Hassanzadazar, H., Ehsani, A., Mardani, K. and Hesari, J. (2012). Investigation of Antibacterial, Acid and Bile Tolerance Properties of Lactobacilli Isolated from Koozeh Cheese. In: Veterinary Research Forum. Faculty of Veterinary Medicine, Urmia University, Urmia, Iran. 3: 181.

Helanto, M., Aarnikunnas, J., von Weymarn, N., Airaksinen, U., Palva, A. and Leisola, M. (2005). Improved mannitol production by a random mutant of Leuconostoc pseudome-senteroides. Journal of Biotechnology. 116: 283-294.

Ketrouci, L., Dalache, F., Benabdelmoumene, D., Dahou, A.A. and Homrani, A. (2021). Technological characterization of lactic acid bacteria isolated from different sheep's milk. Asian Journal of Dairy and Food Research. 40: 239-245.

Kumari, V., Kumar, V., Chauhan, R., Asif, M. and Bhalla, T.C. (2016). Optimization of medium parameters by response surface methodology (RSM) for enhanced production of cutinase from Aspergillus sp. RL2Ct. 3 Biotech. 6: 149.

Makanjuola, D.B. and Springham, D.G. (1984). Identification of lactic acid bacteria isolated from different stages of malt whisky distillery fermentations. Journal of the Institute of Brewing. 90: 13-19.

Morgan, M.C., Boyette, M., Goforth, C., Sperry, K.V. and Greene, S.R. (2009). Comparison of the biolog omnilog identification system and 16S ribosomal RNA gene sequencing for accuracy in identification of atypical bacteriaofclinical origin. Journal of Microbiological Methods. 3: 336-343.

Nair, P.S. and Surendran, P.K. (2005). Biochemical characterization of lactic acid bacteria isolated from fish and prawn. Journal of Cultural Collections. 4: 48-52.

Ojamo, H., Koivikko, H., Heikkilä, H. and Xyrofin, O. (2003). Process for the production of mannitol by immobilized microorganisms. US Patent No. 6,602,691.

Ortiz, M.E., Bleckwedel, J., Fadda S., Picariello G., Hebert, E.M., Raya, R.R. and Mozzi, F. (2017). Global analysis of mannitol 2-Dehydrogenase in Lactobacillus reuteri CRL 1101 during mannitol production through enzymatic genetic and proteomic approaches. PLoS ONE. 12: e0169441.

Otgonbayar, G., Eom, H., Kim, B.S., Ko, J.H. and Han, N.S. (2011). Mannitol production by Leuconostoc citreum KACC 91348P isolated from Kimchi. Journal of Microbiology and Biotechnology. 9: 968-971.

Padmaja, G.A., Ramachandra, B., Manjunath, H., Prabha, R., Krishna, R. and Shankar, P.A. (2011). Characterization of lactic acid bacteria isolated from fruits and vegetables for their antibacterial activity. Asian Journal of Dairy and Food Research. 30: 85-89.

Ruiz Rodriguez, L.G., Aller, K., Bru, E., De Vuyst, L., Hebert, E.M. and Mozzi, F. (2017). Enhanced mannitol biosynthesis by the fruit origin strain Fructobacillus tropaeoli CRL 2034 Applied Microbiology and Biotechnology. 101: 61-65.

Salehi, T.Z., Mahzounieh, M. and Saeedzadeh, A. (2005). Detection of invA gene in isolated Salmonella from broilers by PCR method. International Journal of Poultry Science. 4: 557559 . 
Optimization and Identification of Lactic Acid Bacteria with Higher Mannitol Production Potential

Sanchez, J. (1998). Colorimetric assay of alditols in complex biological samples. Journal of Agriculture and Food Chemistry. 46: 157-160.

Sharif, N.M., Sreedevi, B., Chaitanya, R.K. and Sreenivasulu, D. (2018). Isolation and screening of Lactobacillus species from dogs for probiotic action. Indian Journal of Animal Research. 52: 1739-1744.
Von Weymarn, N., Hujanen, M. and Leisola, M. (2002). Production of D-mannitol by heterofermentative lactic acid bacteria. Process Biochemistry. 37: 1207-1213.

Yun, J.W. and Kim, D.H. (1998). A comparative study of mannitol production by two lactic acid bacteria. Journal of Fermentation Bioengineering. 85: 203-208. 